\title{
Agribusiness Financing in Australia: Issues and Research Agenda
}

\author{
Mohd. Mohsin ${ }^{1}$ \\ ${ }^{1}$ School of Commerce, University of Southern Queensland, Toowoomba, Australia \\ Correspondence: Mohd. Mohsin, School of Commerce, University of Southern Queensland, Toowoomba, \\ Australia. Tel: 61-7-4631-5362. E-mail: Mohd.Mohsin@usq.edu.au
}

Received: April 6, 2015

Accepted: April 22, 2015

Online Published: June 25, 2015

doi:10.5539/ijef.v7n7p1

URL: http://dx.doi.org/10.5539/ijef.v7n7p1

\begin{abstract}
Purpose: This paper aims to critically synthesises the current agribusiness financing avenues; the role of each financial actor, tools, and regulations; and the implications and policy loopholes therein in Australia.

Methodology: This study has been conducted by investigating and reviewing a vast numbers of literatures including official publications, both national and international, on agribusiness and its financing issues in Australia, Published and unpublished research papers, working papers, seminar and conference proceedings, online resources and scholarly commentaries

Findings: This paper's review findings show that the agribusiness sector in Australia is primarily financed by family sources, commercial banks, and government support finance programs; capital markets, foreign, and special innovative and structured products provide a nascent contribution to financing agribusiness. In contrast, this study has explored several key challenge areas in the Australian agribusiness sector that could simultaneously be translated into opportunities for Australian agribusiness when the policy recommendations are implemented.
\end{abstract}

Original Value: Finally, this paper has coined a research agenda from, the Australian agribusiness financing landscape, to be followed and researched to solve this sector's financing woes.

Keywords: agribusiness, financing, Australia

\section{Introduction}

The agribusiness sector, which comprises the business activities performed from the farm to the consumer's dining table, is now considered a major generator of employment and income worldwide (Konig et al., 2013). The global population is expected to increase from 7 billion in 2012 to 9.1 billion in 2050, a 30 per cent increase; accordingly, the demand for food production and agricultural products will also increase even faster, by approximately 70 per cent over the same period (Food and Agriculture Organization of the United Nations, FAO, 2012). Following the spike in international food prices in late 2007 and 2008, and the resurgence of high prices in mid-2010, the agriculture arena has received increased global attention (Moir, 2011). Studies show that the national and international agribusiness sector and its related industries and policies are very cohesively and functionally related. In addition, a disruption in this sector creates a hunger crisis and malnutrition. Eventually, the entire world would destabilise from the confluence of limited food, limited finances, and economic crises. Food crises, which are the consequence of an unsustainable global and national agribusiness sector, are the most difficult issue to address.

Regarding such global positioning of the agribusiness industry, the Australian agribusiness sector has a long historical legacy and can maintain a significant position in the global agribusiness industry. Australia is one of the world's net exporters; the Australian agricultural sector ranks fourth behind Brazil, Argentina and the Netherlands (Australian Farm Institute, 2009). The Australian agribusiness sector accounts for approximately 3 per cent of global food trade; this is 3 times higher than the domestic demand. The export value of Australian agribusiness products was $\$ 38$ billion in 2012-2013, compared with imports valued at approximately $\$ 12$ billion (Australian Bureau of Agricultural and Resource Economics and Sciences, 2013). Australian farm and fisheries food production was $\$ 42.6$ billion. Australian food exports were valued at $\$ 30.5$ billion in 2011-12, with over 50 per cent of exports going to Asia (Austrade, 2014). Moreover, the Australian agricultural industry is one of the five pillars (Asia Pacific Stock Exchange, 2014); it is also one of the next high growth wave sectors (Deloitte, 2013) of the Australian economy. A vibrant, innovative and competitive agricultural sector and related 
downstream activities are important to the Australian economy and a major driver of economic activity, employment and social cohesion for building stronger regional communities; in addition, a stronger Australian agribusiness sector has played an important role in Australia's history (Commonwealth of Australia, 2014). It represented approximately one quarter of the nation's output in the first half of the 20th century and between 70-80 per cent of Australia's exports (Gray et al., 2014). From an economic standpoint, the farm gate and out of farm gate contributions, including all value added economic activities, farm productions to farm inputs, are approximately 3 per cent and 12 per cent of GDP, respectively (National Farmer's Federation, NFF).

Illustrative of such a pronounced economic contribution and future potential for agribusiness, Australia has had an informal agricultural policy for thousands of years, formalised by the post-European settlement (Commonwealth of Australia, 2014). Hence, it is a real tragedy for the Australian agribusiness sector that it lags behind comparable countries such as the US and Canada in its long-term productivity when using competitiveness as main indicator, although there are a number similarities between these countries. The productivity growth in the US agricultural sector (1.8 percent per year) exceeded that of the Australian agriculture sector (1.6 percent per year) and the Canadian agriculture sector (1.2 per cent per year) from 1961 to 2006 (Rural Industries Research \& Development Corporation, RIIRDC, 2013). Although Australia's growth rate is higher than Canada's, in terms of long-term consistency, it is still less than Canada's (RIRDC, 2013). Geographic proximity, trade investment and cultural links to the fast growing Asia Pacific region offer Australia a cost-competitive agribusiness sector compared with competitors in Europe and North America (Australian Trade Commission, 2014). The most troublesome fact for Australian agribusiness is that this sector is one of the three culprits responsible for a total decline of $80 \%$ in Australia multifactor productivity; mining and utilities are the other two sectors (Productivity Commission, 2011).

With this setting as the backdrop, the Australian government has recently drafted an 'Agricultural Competitiveness Issue Paper' for ensuring and realising agriculture's full potential as one of the five pillars of the Australian economy, through innovation, productivity and trade. The theme 'Access to Finance, Farm Debt Levels and Debt Sustainability' is one of the key issues addressed by Australian agricultural competitiveness (Commonwealth of Australia, 2014). Consistent with this positive initiative undertaken by the government, Part Jackson Partners and ANZ Bank, Australia (2012) has researched the investment landscape, from 2014 to 2050 , for the agribusiness sector; they have determined that A $\$ 600$ billion in capital investments is needed for production growth and that a $\mathrm{A} \$ 400$ billion investment is needed for supporting farm turnover. With this investment, Australia will be able to capture an additional a \$0.7-1.7 trillion in agricultural exports between the current year and 2050. This bodes well for the annual capital gap of \$A9 billion that currently exists today in the agribusiness sector (Part Jackson Partners \& ANZ, 2012).

It is surprising to note that in the presence of such a significant agribusiness investment opportunity, Australia is showing an overall declining level of investment compared to GDP, similar to other OECD (Organization for Economic Cooperation and Development) countries such as the US and UK (Industry Super Australia, ISA, 2014). Another unfortunate story within the agribusiness sector in Australia is that the number of agribusiness firms has fallen by 13 per cent over the past ten years, while the total business population has increased by 11 per cent (Reserve Bank of Australia, RBA, 2013). This declining investment pattern does lead to the interpretation that there are few good opportunities for companies and investors to invest capital in Australia.

Within this setting, this paper is motivated to contribute the criticalities of existing sources of finance for Australian agribusiness by reviewing the available global agribusiness financing and investment models, confronting certain issues of agribusiness finance and discussing a future research agenda. This study has been conducted by investigating and reviewing a vast numbers of literatures including official publications, both national and international, on agribusiness and its financing issues in Australia, Published and unpublished research papers, working papers, seminar and conference proceedings, online resources and scholarly commentaries.

The remainder of this paper proceeds as follows. Following a brief review of the previous empirical literature on traditional and changing views on the financing issues of agribusiness in section two, this paper has identified several major sources of financing with their contributions and criticisms for Australian agribusinesses in section three. Section four investigates some policy loopholes in the macro environmental perspectives that Australian agribusinesses are facing with compare to some comparable economies regarding some international benchmarks. Certain global emerging issues of concern, which could also be barriers to financing Australian agribusinesses, if not confronted in a balanced way, are discussed in section five. Section six contains specific policy recommendations for Australian agribusiness financing. Finally, section seven provides conclusions and certain further issues for a research agenda. 


\section{Review of Literature on Agribusiness Financing}

\subsection{Conventional Thinking of Agribusiness Financing: A Generic Perspective}

Farmers and farm businesses in every economy are highly heterogeneous in terms of production capacity, plot sizes, mechanisation, resources and expertise; they are homogenous with regards to having a limited ability to access finance for farming activities (International Finance Corporation, IFC, 2012). The lenders, financial institutions in particular, face three major areas of challenge in extending their investment portfolio to this sector (IFC, 2012): problems unique to agriculture, high transaction costs, sub-optimal policy and the regulatory environment. Traditionally, in every economy, the simple dichotomy regarding the financial planning of the agricultural sector has been that agribusiness accumulates funds from two sources: equity capital, which is provided solely by farmers who operate farms and ranches; and debt capital from a variety of sources. This unique financing characteristic is unlike the other sectors of an economy (Scofield, 1972). The literature available on finance and the financial economists advocate for this trend citing conventional thinking that the agricultural sector is too costly and risky for investing; this advocacy is based on a so-called 'fundamental' argument that this sector has certain built-in risks and natural and biological uncertainties, which goes beyond even traditional and sophisticated knowledge and risk measurement tools. However, agricultural economists have countered with the opinion that risks and uncertainties also exist in nearly every other venture, depending on the nature of the business, which debt and equity capital suppliers are willing to take. This debate raises a critical issue among financial service providers as to why farm financing should be viewed differently in terms of capital sources (Scofield, 1972). This narrowly focused perception of agribusiness does not only undermine the capital needs in this sector but also pushes the country as well as the whole world into a state of food insecurity. In fact, during the first half of the century, an estimated 85 per cent of the new investment in agriculture derived from farm retained earnings (Spitze, 1961). Scofield (1972) mentioned three factors that tend to make traditional equity capital seriously inadequate for the present or the immediate future: (1) the continuing substitution of capital for labour and land in the production process; (2) the narrowing profit margin in all economic activity in general and in agriculture in particular; and (3) the rising expectation of living standards by farm families.

The World Bank (2014) has identified certain reasons for which financial institutions have, historically, lower credit exposure to the agriculture sector and its supply chain. These include: geographical disadvantages for the farm and farmers; systematic risk factors and their spillover effects on the entire value chain of agribusiness industries; lack of financial infrastructure for tracking, identifying and monitoring potential agribusiness transactions in rural areas; the paternalistic motives and policy attitudes of the government towards agribusiness; and the lack of trust and financial training among agribusiness farms regarding banks and banking products. However, in this regard, it is relevant to note that there are no homogenous factors in every country regarding why agricultural finance has been out of favour in the financial and related industries.

\subsection{Contemporary Thinking on Agribusiness Finance: An Outcome of Sweeping Change}

Financial services has been considered one of the 'important enablers', according to the nine enabling needs for agribusiness and agro-industrial development of Christy et al. (2009). For the following four reasons, banks and other financial institutions are now considering whether financing agricultural enterprise offers them a major growth opportunity (IFC, 2012). First, global food demand is likely to grow 50 per cent by 2030 , meaning that this sector will expand rapidly through strong, profitable buyers. Second, financing allows farmers to invest in new technologies and access better inputs, thus significantly increasing yields and contributing to food security and better incomes. Thus, access to finance will help farmers 'move from the subsistence/semi-commercial' level to become commercial farmers. Third, agricultural lending by formal financial institutions provides an opportunity to diversify larger portfolios. Fourth, innovative financing, risk mitigation, and distribution models hold a certain promise that the risks and costs of agricultural lending can be managed. Given these factors, lenders are beginning to recognise the growing potential and profitability of lending to these 'generally feared but little understood' agricultural enterprises (Doran et al., 2009).

A number of critical factors are responsible for this new development. The rapid rise in food prices and the shortage of basic commodities experienced in 2008 has resulted in increased attention from the public sector; the higher prices and therefore increased opportunity for profits generated interest from the private sector. Investment decisions in agribusiness require placing much more emphasis on assessing future trends and market potential (Miller \& Jones, 2010). In addition, in an era of global markets, local supply and demand has less effect on prices as products more readily flow across borders; this thus changes the nature of price risk within those markets. The agro-food sector has undergone changes that have influenced new models of production and 
marketing; these models now involve a focus on demand rather than on producer-defined agricultural goods. These changes include a global, liberalised and fragmented marketplace with little seasonality and high product diversity; food safety and traceability requirements; and higher quality standards in conjunction with the enforcement of basic environmental regulations (Miller \& Jones, 2010). This evolution requires a better understanding of the entire set of financial transactions within each value chain and that of the agricultural sector within which it operates. Integrated chains are able to do this most effectively. This information is important for making financial decisions. It is recognised that increases in finance and investment are needed at all levels of the food chain, with special interest in increasing the access to finance by those agricultural households and communities who are most vulnerable to food insecurity and poverty.

Kloeppinger-Todd and Sharma (2010) have categorised the most promising developments in agribusiness finance into four thematic areas: tailoring financial services to the business reality of farmers and agribusinesses; using technology to reach out to new clients and reduce transaction costs; developing innovative risk management strategies; and bundling financial instruments with other financial or non-financial services to overcome the multiple constraints faced by farmers and agricultural SMEs. Investment in agribusiness by financial sponsors has also grown significantly over the past decade, as evidenced by the dramatic rise in the number of agribusiness-focused investment funds, the number of deals completed and the investment value of those deals. In 2009, 165 agro-related deals were completed, valued at $\$ 4.4$ billion, compared with 239 deals worth $\$ 6.6$ billion completed in 2013. Most private agribusiness investments between 2009 and 2013 were targeted at producers/processors of commodities and foods, with an average investment of $\$ 31$ million per transaction (Walter, 2014).

\subsection{Agribusiness Financing: A Critical Australian Perspective}

\subsubsection{Agribusiness Fund Availability: Are Short-Termism and the Asymmetric Policy Attitude the Main Culprit?}

The conventional wisdom is that over the past few decades, the Australian financial system has become a more market based financial system, meaning that the sources of funding for the Australian economy originates from equity markets (Initial Public offering, public and corporate bond market, and private equity market) rather than from a traditional intermediation-based financial system in which the funds originate from banks (Eraskine, 2014). Due to the true momentum of equity, bond, private equity and venture capital markets, the classic intermediation of the financial system is continuing its pivotal role in the Australian financial system. This means that the Australian financial system can be said to have a hybrid system. The emergence of short-termism attitudes in Australia, similar to the short-termism in many other countries, (Myners, 2012; Kay, 2012; OECD, 2013; Papaioannou et al., 2013), has created the lack of financing for long-term needs; this has serious implications for the growth of the agricultural sector (Eraskine, 2014). Agriculture is a capital-intensive industry. As such, in a modern competitive framework, the agribusiness firm requires long-term financing for equipment, to guard against constant unpredictable uncertainties, and to address natural disasters such as floods and droughts. This shortage of long-term capital and value centred investors for long-term investment pose different long-term threats to the economy, incomes, jobs and infrastructure; it also distorts the development of the financial system. Short-termism, which is the tendency to overweight near-term outcomes relative to future long-term growth opportunities, appears to be a likely culprit for the above phenomenon. Empirical evidence suggests a game of short-termism in which future cash-flows are discounted heavily (Poterba et al., 1995) and listed firms reject positive long-term investment projects in favour of short-term earnings (Graham et al., 2005). Short-termism is, of course, the byproduct that originates from the incentives and perceptions of banks, corporate managers, superannuation managers, and retail investors; it is also how these incentives are functionally related to public policy, market structure and market regulations. However, the empirical evidence has yet to ensure which intuitional financing arrangement, market-based, bank-based or hybrid system, will best serve the diversified needs of the agribusiness industry in Australia. The fair and balance policy attitude of the financial industry is another matter of concern for Australian agribusiness. The Financial Planning Association of Australia (FPA, 2014) has found that one of the striking limitations of the current Australian financial system is that it does not facilitate equal participation by all financial consumers, for example, agricultural sectors and small and medium enterprises (SMEs). The FPA also comments that the existing Australian financial system strengthens the socio-economic divisions within Australian society as the system does not allow for equal participation in the system by those who have fewer resources and less tolerance for risk.

\subsubsection{Conventional Thinking by Australian Financiers}

Traditionally, family farming has been the cornerstone of agriculture in Australia. However, most interestingly, the RBA still does not have a separate database and also does not profess specialist knowledge of family farming 
(Commonwealth Australia, 2013). Raising capital to expand and sustain family farming operations has become more challenging during the past decade due to ever-decreasing profit margins (Foss, 2013). During this time, Australian farming has experienced some of the most severe climatic variability, volatile commodity prices and escalating input costs.

Historically, Australian agribusiness firms and the farmers have been held captive, at the mercy of weather, the value of the dollar exchange rate and the country's banking sector policy (East \& Partners, 2012). The reasons for the captivity include the response by the Australian government to farmers' loan-related demands regarding guarantees and the higher lending rate of approximately one per cent for the agribusiness sector as compared with mortgage rates; another reason is the approximately double the Reserve Bank of Australia (RBA) cash rate (East \& Partners, 2012). When banks reduce the mortgage rate, they often leave the agribusiness rate intact. The balance of power has levelled between bankers and farmers due to the reduction in the cash rate by the RBA for the first time in November 2012 and, accordingly, the reduction in the farm sector interest rate.

\subsubsection{Contemporary Thinking by Australian Financiers: An Outcome of Sweeping Change}

Changes to the economic environment and social order are forcing agribusiness stakeholders to rethink the existing farm business and financing models that have conventionally underpinned the sector (National Farm Foundation, NFF, Media Release, 2014). With this setting in mind, the Farm Finance Forum has focused on building the financial resilience of Australian farm businesses (NFF, 2014). To exploit the next growth wave in the agricultural sector, financing this sector should be one of nineteen future growth segments and priorities for Australia (Deloitte, 2013). Australia risks missing the golden opportunity for this sector to grow; in addition, Australia risks the falling of this sector into a threatened position regarding its future export competiveness in the world market. These risks are due to six challenges that affect the competitiveness of Australia's food and agribusiness sector (Rado Bank Media Relases, 2014), including rising production costs, both on farms and beyond the farm gates; international market access; logistic infrastructure and inefficiencies; regulatory pressures; capital constraints; and product innovations and development. Australian agriculture and agribusiness are also facing a challenging time regarding certain vital issues: the increase in corporate farming, which is driving vertical integration; rising global demand for produce; opening export markets; the collapse of various agribusiness investment schemes; the emergence of international investors; and genetically modified food (www.hallandwilcox.com.au.) Capital constraint has been identified as a barrier to the future advancement of the Australian agricultural sector (ANZ Insights, 2012). Regarding the capital constraint issue, the report says:

"Farmers face significant challenges in raising sufficient capital to fund growth and support farm turnover". New structures for owning and operating farms need to been courage to attract investment form domestic and foreign sources and capital markets. These structures might include rapidly evolving equity partnership, modern variants of share farming and the use of off-take agreements".

\section{Findings: Lessons Learned from the Australian Agribusiness Financing Model}

\subsection{Banking Channel: The Contributions and Criticisms}

The banking industry has been a critical component of the agriculture sector since the late 1800s, working with primary producers and farming businesses in rural and regional Australia (Australian Bankers' Association, ABA, 2014). Australian agricultural financing has a long history in which the major lenders, the Big Four, did not have the agribusiness sector as a particular focus (Crop Update, 2013; East \& Partners, 2012). The Australian agribusiness sector sought 32 per cent of debt financing from the country's banking channel over the two years ending June 2011 (Australian Business Statistics, ABS, 2011). In comparison, the average across all industries is 17 per cent. The growth in outstanding credit in the agriculture sector from banks has averaged $1 \%$ over the last 4 years; all major lenders do not nourish the farm sector in the same way as they nourish the mortgage market and other commercial businesses. Financial innovation in this sector has been sluggish and usually government generated (Crop Update, 2013). Several notable agribusiness financial products and services delivered by the Australian banking channel are farm management accounts; farm management deposits; farm management overdraft; farm equipment finance; farm loan packages; domestic and international agribusiness trade finance; and agribusiness-related risk and insurance coverage for commodity price volatility and natural catastrophes. Financial counselling on the issue, such as writing agricultural business plans, identifying the financing options, negotiating with lenders, farmer accounting and legal assistance, are provided through rural financial counsellors. At an individual bank level, Australian banks have financial literacy programs to assist their customers with money management, business planning, and financial and estate planning. Specifically, banks have resources to assist agribusiness customers, including dedicated areas of their bank websites (ABA, 2014).

On the supply side of financing, the Australian agribusiness sector has pronounced structural problems. The 
Australian banking sector's lending portfolio has been decidedly focused on the household sector rather than the business sector (Stewart et al., 2013). Davis (2011) notes that residential loans in Australia constituted nearly 60 per cent of Australian banks' total loan portfolios in 2009. Family farming faces certain concerns from authorised Australian lenders (Common Wealth of Australia, 2013): the lack of competition between lenders; inappropriate terms and conditions of financing within products offered by the lenders; and the inappropriate risk rating by financiers. The IMF (2012) has also found that Australian banks have a high concentration in household debt, which may create housing price risk in Australia; the combination of high household debt and elevated house prices is a risk to banks' large mortgage portfolios in Australia. Conversely, the agribusiness sector contributes small deposit amounts relative to its borrowing. This means that a high demand for debt from the agro sector is met by funds sourced from other sectors including industries, investors and households. The conflict of deposits and borrowing poses a maturity mismatch problem for liquidity management by banks. The reason for this is that the maturity of agribusiness sector loan products, although not all agribusiness products, are usually long term in characteristics. On the other hand, banks generally are money market institutions, which promise to repay the depositors' money on demand. This creates an obligation to invest the depositor's money in those projects that will be relatively short term and that will generate a regular stream of cash flows. In addition, banks in Australia assess the loan application for agribusiness customers considering all available sources of income, cash flow streams of the project and the loan security (ABA, 2014). These traditional lending norms do not match the typical agribusiness sector, as the underlying value of the loan contracts in the agribusiness sectors are at risk. These risks derive from variable earnings and cash flows originating from the seasonal and weather variability, direct and indirect regulatory interventions, changes in industry policy and other interventions (ABA, 2014). The direct regulatory risks are associated with the changes that affect the enforceability of the contract, while the indirect regulatory risk comes from the changes of the regulations of the use of natural resources (land, water, vegetation and access to minerals and gas).

Due to their dependence on natural biological and physical processes, farm businesses have long development and life cycles (Santhanam-Martin, 2014). Their returns are also highly variable from year to year due to both natural factors (such as weather) and high volatility in the prices of both inputs and products. For these reasons, the claim is often made that agriculture needs 'patient investors' willing to expose themselves to more of the business' risks and with an eye on the medium and long term (Santhanam-Martin, 2014). This would be equity investment rather than debt; this, of course, has its own particular pros and cons.

\subsection{The Public Equity Market: The Contributions and Criticisms}

Unlike the finance sector, the agricultural sector had not seen the benefit of recent developments in the Australian financial system, best reflected in the 1997 Financial System Inquiry (Wallis Report). This inquiry addressed how Australia funds its growth, domestic competition, international competitiveness, and the current cost, quality, safety and availability of financial services, products and capital for users (APX, 2014). Agribusiness is significantly under-represented in the equity market listings for a number of reasons including investment horizon expectations and gaps and variability of returns owing to climatic conditions (APX, 2014). Agriculture constitutes less than 1 per cent of the ASX, and there are dozens of listed agriculture stocks (Brown, 2012). The ASX has also served as a platform for the ASX Grain market over the last 10 years by providing the Futures and Options Market for Australian Grain. This grain market facilitates various opportunities to hedgers and investors to manage their respective interests in Australian wheat, feed, barley, sorghum and canola (ASX, 2014). There are unlisted managed funds (mFund) on the ASX platform with a soft commodity and agribusiness focus, including the Deutsche Bank-led DWS Global Equity Agribusiness Fund and the Colonial First State Global Soft Commodity Share Fund.

Since the late 1990s, agribusiness Managed Investment Schemes (MIS) have been a popular form of investment for many retail investors, with much of that popularity attributed to special tax concessions associated with those investments. The Australian Securities Exchange Commission, (ASIC, 2009) reports that in July 2009, there were 371 licensed agribusiness schemes of which 198 were forestry (plantations) and the remainder primarily horticultural; in addition, approximately $\$ 8$ billion had been raised from 75,000 investors since the introduction of the Managed Investments Act in 1998.

The ASX has not been used thus far to raise the necessary capital needed for the agribusiness sector. When critically investigated, the reasons are found to be multifaceted. The risk-return portfolio of this sector does not match with the risk-return portfolio of other similar alternative forms of investment (Challenger, 2012, cited by Brown, 2012). The limited knowledge of farming among the fund managers, the lack of a sufficient background with agribusiness investment mechanisms and a lack of an agribusiness-associated corporate governance history among the investors are also creating barriers to capitalising on the capital market opportunity. 
Investors have lost faith in the managed investment schemes due to various factors such as financial deception, false information in the audit report (Australian Securities and Investment Commission, 2009), tax treatment, insolvency, administration arrangements, and disclosure falsifications (parliamentary Joint committee Inquiry, PJC, 2009). The collapse within one month in April/May 2009 of two of the largest operators of such schemes (Great Southern and Timber Corp), accounting for approximately 40 per cent of the industry, has cemented the loss of confidence among investors. There are also several instances where 'Corporate Big Fish' are involved in obtaining a personal financial advantage based on producing false documents and making false information available to the auditors. For example, Mr. Clionton Cordon, former President of Bustan Australia Holdings Pty and Bustan International Pty Ltd, was charged by the court on proof that he was responsible for driving a material loss of $\$ 5.97$ million by issuing unqualified audit reports for the years 1999/2000 and 2000/2001 (ASIC, 2009).

The literature and available sources show that there is no separate agribusiness index in ASX, unlike other sectorial indices. This unavailability does not help agribusiness investors regarding market performance and future market forecasts for agribusiness products. The Commonwealth bank, however, has constructed an Agribusiness Index for Australian agribusiness of its own initiative. The Commonwealth bank Agribusiness Index began on 3 April 2000, which is the same date as the launch of the S\&P /ASX index series in Australia (Commonwealth Bank, 2011). At inception, there were 8 stocks included in the stock index. The number is currently 16.

\subsection{Private Equity (External Equity): The Contributions and Criticisms}

The private equity (PE) business model is well established in Australia (Deloitte, 2013) and is on the rise in Europe and North America (Thompson Financial, cited by Mondelli, 2011), and in New Zealand (Wilson, 2006). Research (Deloitte, 2006) shows that Australian PE investors are involved in a wide range of industries, particularly manufacturing, utilities, trade, accommodations, health and other services. However, PE investors are underrepresented in family based agribusinesses (Midsnell Group International, MGI, 2006) and in primary industries, such as agribusiness and construction (Deloitte, 2013). A Grant Thornton study on Global Private Equity (2013) finds that as recently as 5 to 10 years ago, the agricultural sector was not a convincing investment option for private equity investors due to the idiosyncratic attributes of agribusiness (Mondelli, 2011), such as random production shocks and seasonal cyclical variations. However, PE investment in the agribusiness sector in Australia is underrepresented due to the following factors: the conservative attitude of ownership retention of agribusiness farms by the family (MGI Australia, 2006); the 'keep it in the family' tradition of equity governance (Bond University, 2012); and the aptitude of unusual cash return expectations, usually three times that of PE investment multiples, of the PE investors (Deloitte Private, 2012).

\subsection{The Foreign Capital: The Contributions and Criticisms}

Foreign investors, including state owned enterprises (SOEs), have shown significant interest in Australian agricultural land and agribusiness. This has occurred because of the widespread demutualisation of the former agricultural cooperatives and the presence of expanding investment opportunities in this sector (Kirchner, Stephen, 2014). Ninety-nine per cent of agricultural businesses in Australia are entirely Australian owned, 89 per cent of agricultural land is entirely Australian owned, and 91 per cent of water entitlements for agricultural purposes are entirely Australian owned (Moir, 2011). In 2009-2010, only 1.6 percent (or $\$ 2.33$ billion) of approvals for foreign direct investment were in agriculture, forestry and fishing, with a further 2 percent $(\$ 2.82$ billion) in food, beverage and tobacco manufacturing (Foreign Investment Review Board, FIRB, 2011).

However, surprisingly, the Australian public has expressed the most negative perception regarding FDI in the agribusiness sector, according to a poll conducted by Essential Media in 2012 (Kirchener, 2014). The poll shows that the largest portion of the Australians surveyed, 41 per cent, thinks that FDI in the agribusiness sector is bad, while 31 per cent, 30 per cent and 26 per cent of public opinion, respectively, opposed FDI in the finance, manufacturing and mining sectors. Opposition to this FDI is rooted in the causes of national and cultural identity and in an evaluation of economic costs and benefits and their spillover effects (Kirchner, 2014). Moreover, Australia has a more regulatory restrictive regime for FDI than the Organization for Economic Co-operation and Development, or OECD, average and is more restrictive than the comparable economies of the US and UK (OECD, Regulatory Restrictive index, 2012).

There has been a host of agro-food business purchases in Australia during the past two years, including more than 750,000 hectares of sheep and wheat land being purchased by Hassad Foods of Qatar; approximately 250,000 hectares of Victoria's western district farmland being purchased by the Alberta Pension Fund; CSR Sugar being sold to Wilmar International of Singapore; Tully Sugar being sold to China Oil and Fuel; and Australia's major 
grain-trading company, AWB, being acquired by Canada's Agrium company (Lawrence, 2012). Moreover, today, foreign companies control more than half of the Australian wheat export industry, approximately $60 \%$ of raw sugar production, and $40 \%$ of lamb and beef processing. These foreign investment trends in the Australian agribusiness sector are criticised by different financial economists and commentators regarding the foreign companies needing to protect their interests and increasing their stakes in Australian agriculture. Lawrence (2012) has been very instrumental in FDI in Australian agribusiness by categorically deeming this FDI as a 'land grab' in developing nations, while for developed nations, this is termed 'foreign direct investment' and is welcomed as capital necessary for economic development.

It is true that, on the one hand, FDI substantiates and compounds the capability of host country investment, also known as 'crowding' or, in effect, the tempo of the host country. On the other hand, the flow of foreign capital can paralyse domestic industries by de-energising the financial, labour and physical capital; this is termed a 'crowding out effect'. For the crowding out effect, domestic interest rates may rise, which may make borrowing unaffordable for certain domestic firms, if foreign farms borrow from host country's financial market under the condition of scarce resources (Sun, 2002). To avoid possible downside effects, the widely accepted National Interest Test, is applied to assess the merits of FDI, although there are huge debates on the conceptual issues in the test (Roskin, 1994; Evans \& Grants, 1991; Department of Foreign Affairs and Trade, 1997; DFAT, 2002). Another issue of FDI in an Australian agribusiness project is acceptance by the Foreign Investment Review Board (FIRB) of Australia. The general business threshold applied to agribusiness is 15 per cent or more of the entity valued at \$224 (Coalition Policy, 2012). However, critics says that the threshold and the National Interest Test, in screening agribusiness projects, actually reflects a poor image of Australian free market credentials (Gaylord, 2001; Nahan, 2001; Tenebaum, 2001). Thus, there was a call from different corners for clarification of the national interest policy in Australia and removal of this 'protectionist relic', in the guise of national interest, from the legislative procedure, as this policy does not match the free market principles of the Australian government (Financial Times, 2005). On the contrary, setting high thresholds and a high national interests' barrier would generate financing difficulties for Australian agricultural producers, to the extent that any reduction in the appetite for foreign investment in agricultural assets may make banks lower their assessment value of collateral and hence make banks become more wary of lending to the sector (Coalition Policy, 2012). Real estate, banking, civil aviation, airports, shopping, broadcasting, newspapers and telecommunication sectors are treated as sensitive sectors; therefore, restrictions are imposed on these sectors regarding FDI (Australian ACT, 1975).

\section{Policy Deficiencies from Global Financial Context}

\subsection{Global Competitiveness Context}

A sophisticated financial market is a precondition that will ensure the availability of capital for private sector investment from such sources as loans from a sound banking system, capital from a well-regulated securities exchange, venture capital and other financial products (World Economic Forum, WEF, 2014). The sub-pillars mentioned in Table 1 show that the competiveness of Australian financial development lags in many areas, notably, in the availability, affordability and accessibility to financing. However, the sub-pillars are not disregarding the agribusiness sector in particular; this study assumes that the problems are reasonably true for Australian agribusiness financing. As the discussion of the paper shows, this sector remains outside the focus area of mainstream finance.

Table 1. Australia's position in financial development

\begin{tabular}{lll}
\hline Eight Sub-Pillars of Financial Development & Rank (out of 148 Countries) & Score (out of 7 score) \\
\hline $1^{\text {st }}$ Sub-Pillar: Availability of Financial Services & 21 & 5.60 \\
$2^{\text {nd }}$ Sub-Pillar: Affordability of Financial Services & 36 & 4.90 \\
$3^{\text {rd }}$ Sub-Pillar: Financing Through Local Equity Market & 8 & 5.00 \\
$4^{\text {th }}$ Sub-Pillar: Ease of Access to Loans & 28 & 3.50 \\
$5^{\text {th }}$ Sub - Pillar: Venture Capital Availability & 19 & 3.60 \\
$6^{\text {th }}$ Sub -Pillar: Soundness of Bank & 9 & 6.40 \\
$7^{\text {th }}$ Sub Pillar: Regulations of Securities exchanges & 11 & 5.50 \\
$8^{\text {th }}$ Sub-Pillar: Legal Right Index (1-10,10 is the max score ) & 1 & 10 \\
Overall Rank & 21 & 5.10 \\
\hline
\end{tabular}

Source: The Global Competitiveness Report World Economic Forum, 2013-14. 


\subsection{Capital Access Context}

The Milken Institute's Capital Access Index (CAI) enables countries to confirm how they compare with others in terms of creating the conditions necessary for firms to raise capital; in addition, this index assists countries in determining what actions can improve the required linkage between finance and economic growth (Barth et al., 2009). It shows the relative strength of financing for businesses in different countries. Most importantly, the CAI index points to the direction in which improvements could be made to broaden access to business finance, which is critical to a country's sustainable economic growth. Each country on each dimension and figure in the parenthesis represents the respective country's rank. The measures regarding capital index in table 2 indicates that Australia has loopholes in its macroeconomic policies, bond market development and international funding arrangement. This research finding by the Milken Institute, although produced in 2010, still has certain implications for the improvement of capital accessibility in Australia.

\subsection{Financial Development Index}

Financial development includes the factors, policies, and institutions that lead to effective financial intermediation and markets, as well as to deep and broad access to capital and financial services (WEF, 2011). With this definition, the WEF (2011) has constructed a financial development index of 60 countries around the world. The 7 pillars are shown in table 3. Although Australia ranks at number 2 in terms financial access, it still lacks sound policies in other areas, particularly an institutional environment, business environment and financial markets. It is worthwhile to note that access to financial services by end users is influenced by the performance of other pillars.

Table 2. Capital access index of australia and comparable counters

\begin{tabular}{lllllll}
\hline CAI components & Canada & Hong Kong & UK & Singapore & US & Australia \\
\hline Macroeconomic environment (ME) & $9.50(2)$ & $9.67(1)$ & $8.17(11)$ & $9.50(2)$ & $7.67(22)$ & $7.00(37)$ \\
Institutional environment (IE) & $8.47(4)$ & $8.35(6)$ & $8.47(4)$ & $8.88(1)$ & $8.35(6)$ & $8.35(6)$ \\
Financial and banking institutions (FI) & $8.60(2)$ & $7.90(5)$ & $7.10(12)$ & $7.80(6)$ & $7.80(6)$ & $8.20(3)$ \\
Equity market development (EM) & $6.17(21)$ & $6.50(14)$ & $6.67(13)$ & $5.83(28)$ & $7.83(2)$ & $7.33(5)$ \\
Bond market development (BM) & $7.75(5)$ & $5.25(33)$ & $8.25(1)$ & $6.25(23)$ & $7.75(5)$ & $6.25(23)$ \\
Alternative sources of capital (AC) & $8.50(3)$ & $7.75(7)$ & $9.00(1)$ & $6.00(22)$ & $8.50(3)$ & $8.50(3)$ \\
International funding (IF) & $6.58(12)$ & $7.42(1)$ & $6.92(9)$ & $7.33(3)$ & $6.83(10)$ & $6.50(14)$ \\
Overall CAI Rank & 1 & 2 & 3 & 4 & 5 & 8 \\
\hline
\end{tabular}

Source: Milken Institute, CAI Index, 2010, figure in each cell represents the score out of 10 of.

Table 3. Financial development status as per the financial development index

\begin{tabular}{llllllc}
\hline Seven Pillars of Financial Development & Canada & Hong Kong & UK & Singapore & US & Australia \\
\hline $1^{\text {st }}$ Pillar: Institutional Development & $5.90(3)$ & $5.70(9)$ & $5.86(6)$ & $6.14(1)$ & $5.59(13)$ & $5.45(18)$ \\
$2^{\text {nd }}$ Pillar: Business environment (IE) & $5.73(9)$ & $5.96(3)$ & $5.70(10)$ & $5.99(2)$ & $5.70(11)$ & $5 T .54(12)$ \\
$3^{\text {rd }}$ Pillar: Financial Stability & $4.97(12)$ & $5.58(4)$ & $4.21(42)$ & $5.44(8)$ & $4.20(42)$ & $4.95(13)$ \\
$4^{\text {th }}$ Pillar: Banking Financial Services & $4.63(13)$ & $5.49(3)$ & $5.51(1)$ & $4.40(16)$ & $4.19(21)$ & $5.16(7)$ \\
$5^{\text {th }}$ Pillar: Non-Banking Financial Services & $4.04(7)$ & $3.73(10)$ & $4.48(4)$ & $3.35(12)$ & $6.01(1)$ & $3.90(8)$ \\
$6^{\text {th }}$ Pillar: Financial Markets & $4.06(12)$ & $4.42(8)$ & $4.81(3)$ & $5.04(2)$ & $5.65(1)$ & $4.37(9)$ \\
$7^{\text {th }}$ Pillar: Financial Access & $4.68(5)$ & $5.29(1)$ & $4.42(9)$ & $4.41(10)$ & $4.82(4)$ & $5.17(2)$ \\
Overall Rank & $6(4.86)$ & $1(5.16)$ & $3(5.00)$ & $4(4.97)$ & $2(5.15)$ & $5(4.93)$ \\
\hline
\end{tabular}

Source: World Economic Forum, 2011.

\section{Other Emerging Issues of Concern}

\subsection{The Financialization of Agribusiness: The Risks of Excessive Flow of Financing}

Numerous empirical studies have proved that finance, financial actors, financial markets, and financial institutions are performing an active role in every aspect of agribusiness value chains worldwide: food retailing (Burch \& Geoffrey 2009, 2013), food processing (Rossman, 2010), grain trading (Murphy et al., 2012), the determination of food prices and the distribution of agricultural risk (Clapp, 2012; Ghosh et al., 2012; Breger, 2012; Spratt, 2013), the provisioning of agricultural inputs (Ross, 2008; The Economist, 2009), and the ownership and control of farmland (Fairbairn, 2013; Highquest, 2010; Cotula, 2012). At the same time, 
enterprises that operate in each of these activities are increasingly active in financial markets and earning a growing share of their revenues from financial activities. These dual roles of the financial and other organisations of agribusiness sector put them in a conflict of interest and creates the platform for exploiting the industry for the profit motive and also the power of dominance in dictating the input and output prices (Iskason, 2013). The total picture has been of Financialisation unusually calculating as sovereign wealth funds, investment houses, private equity consortia and others dealing in financial instruments such as credit default swaps, derivatives, bonds, securities and futures trading have been increasing their investments in agriculture, worldwide (Lawrence, 2012). Political economists raise the questions regarding the integrity of such Financialisation motives, as many analysts noted that this sort of profit making motive from the commodity market is one of the root causes dramatic increases of food prices in 2007-2008 (Isakson, 2013).

Financialisation refers to the increasing importance of financial motives, financial actors, financial markets, and financial institutions in the operation of economies and their governing institutions, both at the domestic and international level. For Krippner (2011, p. 4), this process can be understood as 'the tendency for profit making in the economy to occur increasingly through financial channels rather than through productive activities (Arrighi, 1994). Agri-business has a number of risks factors: weather, pests, plant diseases, and market prices. Through modern financial instruments such as derivatives and micro insurance, agricultural risks have become financially productised.

Having said this dark side of finance, this paper likes to draw the attention of all the stakeholders of Australian agribusiness, particularly the financial industry, regarding the nature of role and their motives of participation in agribusiness industry. Some scholars have argued that the role of finance would be as servant to the agro food economy rather than the master (Isakson, 2013) while others opine that there might be a good compromise between the profitability goal of the financial actors and the price efficiency goal of the society.

\subsection{Best Agribusiness Practices for Agribusiness Financing}

From the available literature, it is evident that there remains a dearth of globally accepted agribusiness standards, best practices and approaches for countries to follow to increase innovation, productivity growth and sustainability in agriculture and to conduct cross country comparisons for exploring the gap. To this end, OECD is developing a wide range of questionnaires for countries to use in analysing national approaches and in demystifying the growth calculus of the agricultural sector (OECD, 2013). Australia, Brazil and Canada have been chosen to review the questionnaire as a framework to examine policy incentives and disincentives that affect agricultural innovation. The best agribusiness financing practices surely have wide implications in the Australian agribusiness sector as they help the country uncover policy in this industry by comparatively analysing cross-country benchmarking.

\subsection{The Global, National and Corporate Governance Issue in Agribusiness Financing}

Sound governance at all levels, including the global, national and corporate levels, is a critical success factor for the long-term sustainability of any institution, although the dimensions of these three are different. Global governance has relevance to the agribusiness sector for issues including but not limited to financial speculation in commodity markets; protection of domestic agribusiness markets from import surges and unfair dumping practices; and international arrangements that stabilise commodity prices and prevent agribusinesses from exploiting low prices and unequal competition (D. Anderson, 2009). These issues can provide the basis for future empirical research into the aspects of Australian agribusiness financing.

The trends of national monopolies and oligopolies that wield excessive power over farmers and consumers, the loopholes in corporate taxation, the emergence of publicly managed food reserves, the revolving door between corporations and positions of government control over research, the distribution of agricultural support, trade and policy, and the need for democratic decision-making institutions governing food and agricultural policy with full accountability to the public, are viable and frequently discussed topics with regard to agribusiness financing in national governance.

The recent financial crisis has been a particularly severe wake-up call for sound corporate governance around the world because it has adversely affected employment, consumer spending, pensions, the finances of national and local governments worldwide, and the global economy. Weaknesses in corporate governance structures within companies and banks, skewed incentive compensation for senior managers, and the predominance of a board culture that values short-term gains over sustained, long-term performance were cited as reasons for excessive risk taking (Claessens \& Yurtoglu, 2012). However, the most striking issues of corporate governance that are considered highly correlated with agribusiness: price and profit transparency along the value chain and the proportion of net revenue earned at the production stage versus other stages in the value chain (D. Anderson, 
2009). Research is also still lacking regarding how the governance system of family businesses, with its different cultural characteristics, capabilities and competitive advantages, is linked with superior financing model.

\subsection{Succession Planning in Agribusiness: A Matter of Concern for Australian Financial}

Succession planning in agribusiness refers to that of agribusiness business plans, which articulates the issues of transferring the ownership, income and operations of the farm business. (Hicks et al., 2014).The present state of succession planning in the Australian farming industry is still underdeveloped (Hicks et al., 2014) and does not adequately plan for succession (Commonwealth of Australai, 2013). The current literature shows that unlike other corporate sectors, the Australian agribusiness sector has still not seen any financial planning, products, or services from the financial industry to facilitate a successful succession of a farming business. This paper hypothesises that this is one of the issues that has a serious financial implication in Australia.

\section{Ways Forward: Policy Suggestions for Australian Agribusiness Financing}

In recent times, there is debatable hype among public and private policy holders, financial actors, researchers, and academicians related to Australian agribusiness that Australia can be a 'Food Bowl of Asia'. Critics argue that claiming such an idea certainly exaggerates the facts. Farmers face significant challenges in raising sufficient capital to fund growth and support farm turnover. Farm debt levels are already high, and few external sources of equity capital are available to farmers in Australia (ANZ, 2012). Our research findings also show that Australia still has numerous problems regarding agribusiness financing and still lags behind some comparable economies in nearly every area relating to the financial development index, financial competitiveness issues, capital accessibility index, and other relevant, significant policy areas. Hence, this research article has identified several policy measures that Australia can apply to develop the stage of its agribusiness financing spectrum and to eventually be the food bowl of Asia by promoting its agribusiness products, services, markets and institutions.

First, this paper suggests that the Australian agribusiness sector can benefit when a proven global farm funding model is replicated. The ideal models of interest could be the Product Bond utilised in Brazil, the equity partnership model of New Zealand and the Community Supported Farm Scheme and farm leasing arrangement in the US. To enhance the financial strength of agribusiness, the Australian banking industry can also create tailored products using a structured financing model proposed by structured finance. Structured finance (SF) involves the advance of funds to enterprises to finance inputs, production and the accompanying support operations, using certain types of security that are not normally accepted by banks or investors and that are more dependent on the structure and performance of the transaction, rather than on the credit worthiness of the borrower (Winn et al., 2009). SF is widely used in most of the agriculturally flourishing Latin American countries (Winn et al., 2009). Structured finance instruments can be clustered into major categories (Win et al., 2009): lending secured by financial assets, such as the assignation of future payment streams, with more or less predictable cash flows (e.g., receivable-backed financing, factoring, and forfeiting); lending secured by physical assets forming, in part, the underlying commodity transactions (e.g., warehouse receipts financing, and repurchase agreements); and securitisation techniques based on selling claims on physical or financial assets in secondary markets (asset-backed securities, loan portfolios, and accounts receivables).

Second, the ASIC, ASX and RBA should develop listed agribusiness equity capital markets with high corporate governance standards and flexible listing regimes that meet the needs of users with appropriate financial products and services. The development of liquidity in innovative equity markets will help Australia become a leader in the transition from venture capital to public listings (APX, 2014).

Third, the Australian government should take initiative to increase the depth of the country's bond market, particularly for the agribusiness sector. To this end, farm management bonds, a specialised bond (similar debt instrument), could be developed as suggested by ABA, 2014. These debt instruments enable investment risk to be shared across public and private investors and to leverage capital markets (i.e., innovation within financial service providers, capacity of investors, and expertise of service providers).

Fourth, the ASX should construct a separate index, particularly for the agribusiness sector. The agribusiness indices will continuously provide market information to domestic and foreign investors regarding past, present and future fundamental and industry development.

Fifth, the legal framework should be created for the public offering of non-voting common shares as a credible step towards accelerating equity capital for the agribusiness sector (APX, 2014). In global competitive markets, in which companies can seek to list internationally, Australia's equity market would be more attractive if entrepreneurs and agribusiness companies could raise equity capital without necessarily having to cede control of decision-making. Some principal competitors of regional stock exchanges, including the NYSE and Nasdaq, 
permit the issuance of non-voting ordinary shares; this affords companies listed on those exchanges a more flexible framework for raising capital. This could help facilitate capital raisings without ceding control of the listed company; thus, it may be one mechanism for retaining ownership and family control.

Sixth, the Australian institutional investors should be encouraged to diversify their investment portfolio into the agribusiness sector. Low levels of institutional investments, such as superannuation funds, in Australia have played a much smaller role in Australian agriculture than in certain other countries. In the United States, it has been estimated that non-owner-operating investors, such as institutional investment funds, owned approximately 29 per cent of farmland in 2007 (Global Ag Investing, 2012). Lower levels of institutional investment in Australian agriculture could be due to farm business assets being less easily converted into cash, or due to the volatility in cash flows.

Seventh, taking value chain financing as a new financing approach for agribusiness and promoting a balanced collaboration among the various agribusiness players in the value chain can be another step towards the development of the agribusiness sector. Rather than considering agribusiness as a traditional isolated producer-based sector of the economy, the agribusiness and agro-food sectors of Australia should consider a strong collaboration between each agribusiness stakeholder. This suggestion follows the new philosophy of the agribusiness chain, which is supported by many scholarly studies. For example, this provides access to new skills and resources and promotes innovation (KPMG, 2013), brings the agro product from production to the final consumer, (Miller \& Da Silva, 2007), and ensures production, marketing, high product diversity, food safety, tractability requirements, higher quality standards and the enforcement of basic environmental regulations (Miller \& Jones, 2010).

Eighth, the total efficiency of the agribusiness value chain is needed and its smooth functioning must be ensured for financial service providers. The commodity's entire supply chain targeted for financial services provisions must be working efficiently. That is, input suppliers must have positive annual returns to enable predictability of input supply by producers; producers must have positive annual returns for raw material supply to be predictable to transporters; transporters must have positive annual returns to enable raw material supply to be predictable to processors; processors must have positive annual returns for the supply of processed agricultural goods to be predictable to wholesalers (Miller \& Jones, 2010). These efficiencies in the supply chain should not be assumed but rather understood and verified. It is dangerous to focus on one level of the supply chain, such as production, while ignoring the other levels.

Ninth, to attract the necessary funding for the agribusiness sector, new listed financial instruments and taxation concessions for listed agribusiness investments are needed (APX, 2014). Unlisted agribusiness investment products have a mixed history, with ups and downs, largely driven by a taxation motivation, rather than by agribusiness development and support motivations. The taxation benefits need to be properly targeted. To encourage agricultural production funding, particularly during adverse climatic conditions, consideration could be given to concessions for investing in listed agribusinesses, similar to those proposed for the mining exploration industry (Exploration Development Incentive, 2014).

Finally, cluster-based agribusiness financing can provide new instruments for agribusiness financing as suggested by APX (APX, 2014). A cluster is characterised by a large number of similar enterprises, substitutable goods/services, selling to the same markets, and a nearly identical susceptibility to changes in economic variables. The use of cluster financing in which several agricultural businesses are grouped together and their financing arrangement is conducted on a collective basis allows them to access credit by amalgamating their credit profile and enhancing their collateral (APX, 2014).

\section{Conclusions and Research Agenda}

The funding models available to Australian farmers and agribusinesses have largely remained the same for the last 100 years (Australian Farm Institute, 2014). In this model, farmers and farms use their land as security to obtain financing from banks. However, this traditional model has become outdated in the new era of divergent agro capital demand and a new financial regulatory regime. Being in a comparative advantage position in several agricultural products (Wonder \& Fisher, 1990; Sanderson \& Ahmadi-Esfahani, 2008), more than 70\% of Australian agricultural production is currently exported, and any future increase in production will likely need to be exported; this makes the sector even more export oriented (Andrews et al., 2003). However, to be more competitive in the world market, simply holding a comparative advantage in agribusiness will be insufficient; instead, achieving an absolute advantage would. However, the possession of a comparative advantage by Australia in this sector indicates that the farm and agribusiness sector will remain an important component of the Australian economy (RIRDC, 2014). Therefore, identification of the optimal financial industry, including 
financial actors, products, models, instructions and regulations, that will stimulate more competitive and resilient agribusiness development in Australia will provide specific directions to all stakeholders in the total agribusiness value chain.

The necessity of finance in Australian agribusiness and farming industry is undeniably indisputable. However, a plethora of questions remains unresolved. In this context, this research hypothesises that the importance of the series of questions drawn by Gonzalez-Vega (2006) regarding the connectivity of a country's financial outreach and agribusiness development have an applicable relevance with Australian agribusiness perspectives. If modified to an Australian perspective, the three sets of questions are as follows: Are financial systems in Australia prepared to meet the new demands for financial services arising from the growth of modern agro-food value chains? Will financial intermediaries be equipped to meet these demands and support the rapid growth of production and productivity triggered by the globalisation opportunities? To what extent will the success of the agro business value chains depend on progress toward widening the choice and access of rural financial services in Australia? These are the first questions that are very reasonable to raise when Australian policy makers, economists and commentators are lamenting and questioning the capability of the agricultural sector to attract suitable future capital. The first set of questions produces further questions: What sort of new demands for financial services and products are there from the Australian agribusiness sector, and why are these demands created? Why is the issue of globalisation a critical factor to consider regarding increasing Australian agricultural productivity? Is there any rural lag in the Australian financial system in general, and the banking system in particular, for which a market segment is underserved? The demand for suitable agribusiness financial products is a complicated issue that is impacted by producers' business specific demands (Cannella, 2012), consumer demand for agro products (Shwedel, 2006), and systematic macro environmental factors. Producers' needs for finance vary on the basis of operating expenses (such as seeds, fertilizer, fuel, labour, payroll, insurance and utilities) and capital investments to maintain farm operations. Consumers directly influence the producers' businesses and financial plans by showing a positive attitude in buying products when they find the following attributes: year-round availability, flavour, quality, freshness, convenience, environmental safety, traceability, wholesomeness and practicality, innovativeness, addressing welfare concerns and low prices. The macroeconomic events, such as the global financial crisis and its subsequent effects on both the domestic and international financial industry and prudential financial regulation and its sensitivity to agricultural commodity prices, would certainly force the creation of innovative financial products. Globalisation is one of the changing factors in the agribusiness industry (Vogel, 2006). The Australian agribusiness industry is now a truly globalised industry because it is an industry net exporter and has ample opportunity to exploit the huge Asian market. It is a quite reasonable assumption that Australian agribusiness farms must have the financial structure that would be sufficiently competitive to respond to the multiple requirements of such a globalised industry. The other issue is the rural lag of the Australian banking system. Australian farm businesses have been family business, passed from generation to generation (Australian Government, 2011). Generally speaking, the firm denotes the home (Hicks et al., 2012). A recent research study (Connolly et al., 2011) showed that $15 \%$ of Australians are marginalised or excluded from the main stream because family-owned agribusinesses are at the centre of rural and regional Australia; the study notes that the banking industry has a tremendous lag in its financial depth and outreach in rural Australia.

The second set of questions is as follows: How much will the transformation of agriculture and the development of modern value chains shape the financial access and delivery processes and the ability of financial intermediaries to meet resulting demands? Does the development of agricultural chains contribute new means of support for modernising the financial system, and how much does the emergence of contractual relationships among stakeholders benefit Australia's financial development and outreach? This set of questions, in exchange, poses additional issues, for example, the correlation between Australian agricultural development and Australian financial development and vice versa. Research can be conducted regarding how demand-led financing opportunities for the Australian banking industry can create innovative special and tailored financial products and accordingly accelerate their sustained capacity in the Australian agro industry.

Will the supply of financial services that develops in response to these processes benefit all types of farmers? Which will be included, and which may not? How much will conventional financial systems be able to ease the incorporation of small- and medium-scale farmers into modern agricultural chains? Will the lack of access to financial services become an insurmountable barrier to entry for many traditional farmers? The issues mentioned above can be the basis for interesting empirical or case study based-research in the Australian agribusiness field.

This study is critical on the point that there is no magic bullet, unique formula or single innovative solution to ensuring adequate financing in the Australian agribusiness sector. The solution is to understand the types of 
farmers, farms and value chain they belong to and the products they produce, and then, accordingly, have all the major financers tailor financing products; these financers include the government, financial institutions, and financial markets.

\section{References}

ABA. (2014). Comments on Australian Agricultural Competitiveness Issue Paper. Australian Bankers' Association Inc. Sydney, NSW 2000. Retrieved from http:/www.bankers.asn.au

ABARES. (2013). Agricultural commodity statistics 2013, Australian Bureau of Agricultural and Resource Economics and Sciences, December, Canberra.

ABARES. (2014). Australian Agricultural Productivity Growth: Past Reforms and Future Opportunities. Research Report 14.2, February, 2014.

ABS. (2011). Agricultural Business Almost Entirely Australian Owned.

AFI. (2009). Australian Agriculture's Role in Global Security. Australian Farm Institute Quarterly Newsletter, $6(3)$.

AFI. (2014). Will Agriculture Attract Suitable Future Capital? Australian Farm Institute Quarterly Newsletter, $11(2)$.

Anderson, D. (2009). A Question of Governance: To Protect Agribusiness Profits or the Right to Food? Agribusiness Action Initiatives, November 2009.

Andrews, N., Buetre, B., Davidson, A., McDonald, D., \& Jotzo, F. (2003). Agricultural trade reform: Benefits for Australian broad acre agriculture. Australian Commodities, 10(2), 249-259.

ANZ, \& Port Jackson Partners. (2012). Greener pastures: The global soft commodity opportunity for Australia and New Zealand. ANZ Insight Series, 3. Retrieved from http://media.corporateir.net/media_files/IROL/24/248677/ANZ_insight_3_Greener_Pastures

Arrighi, G. (1994). The Long Twentieth Century: Money, Power, and the Origins of our Times. New York: Verso.

Asia Pacific Stock Exchange (APX). (2014). Agricultural Competitiveness White Paper Submission-IP309, Asia Pacific Stock $\quad$ Exchange $\quad$ Limited. Retrieved from https://agriculturalcompetitiveness.dpmc.gov.au/sites/default/files/public-submissions/ip309_asia_pacific_s tock_exchange_limited.pdf

ASIC. (2009). Annual Report. Retrieved from http://www.asic.gov.au/reports\#2009

Austrade. (2014). Investment Opportunities in Australian Agribusiness and Food, the Australian Government, Sydney, NSW, 2011.

Australian Government Productivity Commission. (2010, 2011). Annual Report.

Australian Government. (2011). Australian Farms and Farming Communities. Retrieved from http://australia.gov.au/about-australia/australian-story/austn-farmsandfarming-communities

Australian Stock Exchange (ASX). (2014). The Futures and Options Market for Australian Grain. Retrieved from http://www.asx.com.au/documents/products/grain-futuresbrochure.pdf

Barth, J. R., Li, T., Lu, W., \& Yago, G. (2010). Capital Access Index 2009: Best Markets for Business Access to Capital. Milken Institute, 15-19.

Bond University. (2012). Bond University, Australia's Submission to the Inquiry into Family Business.

Breger, B. S. (2012). Derivatives and Development: A Political Economy of Global Finance, Farming, and Poverty. Palgrave Macmillan.

Brown, B. (2012). Tapping into the Agricultural Boom. Australian Financial Review. Retrieved from http://www.afr.com/p/personal_finance/smart_money/tapping_into_the_agriculturalboom_GebwKalqMhEi 7XL6v4KNFJ

Burch, D., \& Geoffrey, L. (2013). Financialization in Agri-food Supply Chains: Private Equity and the Transformation of the Retail Sector. Agriculture and Human Values.

Cannella, D., \& Geoffrey, L. (2009) Towards a Third Food Regime: Behind the Transformation. Agriculture and Human Values, 26(4), 267-279.

Christy, R., Mabaya, E., Wilson, N., Mutambatsere, E., \& Mhlanga, N. (2009). Enabling Environments for 
competitive agro-industries. In C. Da Silva, D. Baker, A. W. Shepherd, C. Jenane \& S. Miranda da Cruz (Eds.), Agro-industries for development (pp. 136-185). Wallingford, UK, CABI, with FAO and UNIDO. Retrieved from http://www.fao.org/ docrep/013/i0157e/i0157e00.pdf

Claessens, S., \& Yurtoglu, B. (2012). Corporate Governance and Development: An Update, International Finance Corporation, International Finance Corporation 2121 Pennsylvania Avenue, NW, Washington, DC 20433.

Clapp, J. (2012). Food. Malden, MA: Polity Press.

Coalition Policy Discussion Paper. (2012). Foreign Investment in Australian Agricultural Land and Agribusiness. August, 2012.

Commonwealth Bank. (2011). Commonwealth Bank Agri Indicators.

Commonwealth of Australia. (2013). Parliamentary Joint Committee on Corporation and Financial Services: Family Business in Australia-different and significant: Why they should not be Overlooked, Parliament House, Canberra, Australia.

Commonwealth of Australia. (2014). Agricultural Competitiveness Issues Paper. Canberra, February.

Cotula, L. (2012). The International Political Economy of the Global Land Rush: A Critical Appraisal of Trends, Scale, Geography, and Drivers. The Journal of Peasant Studies, 39(3-4), 649-680.

Crop Updates. (2013). The 2013 Agribusiness Crop Updates. Crown, Perth, Australia. Retrieved from http://www.giwa.org.au/2013-crop-updates

Davis, J. H., \& Goldberg, R. A. (1957). A Concept of Agribusiness. Division of Research, Harvard Business School, Boston, MA.

Davis, K. (2011). Funding Australia's Future: Where do we begin? Australian Centre for Financial studies, The Funding Australia Future Project.

Deloitte, P. (2012). Deloitte Australasia's Submission to the Inquiry into Family Business, 2013.

Deloitte. (2013). Positioning for Prosperity? Catching the next wave. Deloitte Touche Tohmatsu Limited, UK.

Deloitte. (2013). The Economic Contribution of Private Equity in Australia. The Australian Private Equity and Venture Capital Limited (AVCAL), March, 2013, Deloitte Access Economics Pty. Ltd.

DFAT. (1997). In the National Interest. Canberra: Australian Government Publication Service.

DFAT. (2002). Advancing the National Interest. Canberra: Australian Government Publication Service.

Doran, A., McFadyen, N., \& Vogel, R. (2009). The Missing Middle in Agricultural Finance. Oxfam GB Research, Report. United Kingdom.

East, \& Partner. (2012). Balance tilts in the Agribusiness Lending. Research Note Australia, September, 2012.

Eraskine, A. (2014). Funding Australia's Future: Regulating the Australian Financial System, Australian Center for Financial Studies.

Exploration Development Incentive. (n.d.). Policy Design, Treasury and Department of Industry Discussion Paper, March 2014.

Fairbairn, M. (2012). Just another Asset Class? Farmland Investment and Financialization. Paper presented at LDPI's Second International Academic Conference on Global Land Grabbing, Cornell University, Ithaca, NY (October 17-19.2012)

FAO. (2012). Innovative Agricultural Finance and Risk Management: Strengthening Food Production and Trade in the Transition Region. Working paper, FAO Vialedelle Termedi Caracalla, 00153 Rome, Italy.

Financial Times. (2005). February, 100 Scap the Firb. Financial Times.

FIRB (Foreign Investment Review Board). (2011). Annual Report 2009-2010 and previous issues.

Foss, M. (2012). Corporate Investments in Agriculture. Nuffield Australia Farming Scholar, 2012.

FPA. (2014). Financial System Inquiry, FPA submission, 26 August, 2014.

FSI. (2014). Financial System Inquiry Interim Report, July 2014.

Gaylord, B. (2001). Australia Rejects the Shell Takeover Bid.

Ghosh, J., Heintz, J., \& Pollin, R. (2012). Speculation on commodities futures markets and Destabilization of global food prices: Exploring the connections. International Journal of Health Sciences, 42(3), 465-483. 
Global AgInvesting. (2012). Farmland: An Untapped Asset Class? Retrieved from http://www.globalaginvesting.com/downloads/files/Farmland-an-Untapped-Asset-Class.pdf

Global Agribusiness Outlook. (2014). Strategic analysis of agribusiness investments-with focus on South America.

Gonzalez-Vega, C. (2006). Modern value chains: Toward the creation and strengthening of Creditworthiness'. In R. Quirós (Ed.), Agricultural value chain finance, FAO and Academia de Centroamérica (pp. 45-63). Retrieved from http://www.ruralfinance.org/id/5407

Graham, J. R., Harvey, C. R., \& Raj Gopal, S. (2005). The economic implications of corporate Financial reporting. Journal of Accounting and Economics, 40(1), 3-73.

Grant ,T. (2013). Global Private Equity Report, 2013. Grant Thornton International Ltd.

Gray, E. M., Oss-Emer, M., \& Sheng, Y. (2014). Australian Agricultural Productivity Growth: Past Reforms and Future Opportunities, ABARES research report 14.2, Canberra, February.

Hicks, J., Sappey, R., Basu, P., Keogh, D., \& Gupta, R. (2012). Succession Planning in Australian Farming. Australasian Accounting, Business and Finance Journal, 6(4), 94-110. Retrieved from http://ro.uow.edu.au/aabfj/vol6/iss4/7

High Quest Partners. (2010). Private Financial Sector Investment in Farmland and Agricultural Infrastructure. OECD Food, Agriculture, and Fisheries Papers, No. 33, OECD Publishing.

IFC. (2012). Innovative Agricultural SME Financing Models, International Finance Corporation. In Interna 2121 Pennsylvania Avenue, N.W.Washington, D.C. 20433. Retrieved from http://www.ifc.org

IMF. (2012). Australia: Financial System Stability Assessment. November 2012. IMF Country Report No. $12 / 308$.

ISA. (2014). Financing Australia's Growth: Submission to the Financial System Inquiry, 2 Lonsdale Street Level 39 Melbourne VIC 3000.

Isakson, S. R. (2013). The Financialization of Food: A Political Economy of the Transformation of Agro-food Supply Chains, Critical Agrarian Studies (ICAS), Land Deal Politics Initiative (LDPI) and Transnational Institute (TNI), ICAS Review Paper Series No. 5.

Kaplan, S. N., \& Schoar, A. (2005). Private Equity Performance: Returns, Persistence, and Capital Flows. The Journal of Finance ,60, 1791-1823.

Kirchener, S. (2014). Regulating Foreign Direct Investment in Australia. A Discussion Paper, Financial Service Institute of Australia (FINSIA), 2014.

Kloeppinger-Todd, R., \& Mahohar, S. (2010). Innovations in Rural and Agriculture Finance. Focus Note 18, International Food Policy Research Institute And the World Bank, Washington, DC.

Konig, G., Da Silva, A., \& Mhlanga. (2013). Enabling Environment for Agribusiness and Agro-Industries development. Regional and Country Perspective, Food and Agricultural Organization of the United Nations, Rome.

KPMG. (2013). The agricultural and food value chain: Entering a new era of cooperation.

Krippner, G. (2011). Capitalizing on Crisis: The Political Origins of the Rise of Finance. Cambridge: Harvard University Press.

L.E.K. Consulting. (2014). Executive Insights.

Lawrence, G. (2012). Farms and finance: Barnaby may not like Cubbies sale, but our agriculture Is out for tender. The Conversation Trust ,UK, 17th September, 2012.

MGI Australia. (2006). Family and Private Business Survey, Australia.

Miller, C., \& Da Silva, C. (2007). Value chain financing in agriculture. Enterprise Development and Microfinance13 (2/3), Practical Action Publishing, Rugby.

Miller, C., \& Jones, L. (2010). Agricultural Value Chain Finance: Tools and Lessons, Food an Agriculture Organization of the United States, and Practical Action Publishing, 2010.

Moir, B. (2011). Foreign Investment and Australian Agriculture, Rural Industries Research and Development Corporation (RIRDC), Canberra, November. 
Mondelli, M. P. (2011). External Equity of Agrifood Farms, PhD Dissertation, University of Missouri, December, 2011.

Murphy, S., Burch, D., \& Clapp, J. (2012). Cereal Secrets: The World's Largest Grain Traders and Global Agriculture. Oxfam Research Reports. Oxford: Oxfam International.

Nahan, M. (2001). It is sad Day for Australian Investors. Australian Financial Review.

National Farmers' Federation (NFF). (2012). NFF Farm Facts: 2012. Retrieved from http://www.nff.org.au/farm-facts.html

National Farmers' Federation (NFF). (2014). Farm Finance Forum: Investing in Innovative Idea, NFF Media Release, May, $\quad 2014 . \quad$ Retrieved from http://www.nff.org.au/read/4520/farm-finance-forum-investing-in-innovative.html

OECD. (2012). Foreign Direct Investment Regulatory Restrictive Index. Retrieved from http://www.oecd.org/investment/fdiindex.htm

OECD. (2013). 'Draft High-Level Principles of Long-Term Investment Financing by Institutional Investors' Task Force on Institutional Investors and Long-Term Financing.

OECD. (2013). Agricultural policy monitoring and evaluation 2013: OECD countries and Emerging economies. OECD Publishing.

Papaioannou, P. G., Park, J., Pihlman, J., \& Van der Hoorn, H. (2013). Procyclical Behavior of Institutional Investors during the Recent Financial Crisis: Causes, Impacts, and Challenges. IMF Working Paper $\mathrm{WP} / 13 / 193$, September.

PJC. (2009). Parliamentary Joint Committee on Corporations and Financial Services Inquiry into Agribusiness Managed Investment Schemes. Retrieved from http://www.aph.gov.au/senate/committee/corporations_ctte/MIS/report/report.pdf

Port Jackson Partners and ANZ. (2012). The Global Soft Commodity Opportunity for Australia \& New Zealand, ANZ Insight $\quad$ Series. $\quad$ Retrieved from http://media.corporateir.net/media_files/IROL/24/248677/ANZ_insight_3_Greener_Pastures.pdf

Poterba, J. M., \& Summers, L. H. (1995). A CEO survey of US companies' time horizons and hurdle rates. Sloan Management Review, 37, 43-43.

RadoBank. (2014). Agriculture in Focus 2014: Competitive Challenges. Media Release, April, 2014.

RBA. (2013). Bank Lending to Agricultural Industry. Reserve Bank of Australia.

RIRDC. (2013). Cross County Comparison of Agricultural Productivity: An Australian Perspective. Publication no, 13/001, March, 2013

Roskin, M. G. (1994). National Interest from Abstraction to Strategy. Carlisle Barracks. PA: Strategic Studies Institutes US ARMY War College.

Ross, A. (2008). Profiting from food crisis can be hard to stomach. Financial Times.

Rossman, P. (2010). What 'Financialization' means for food workers. Seedling, 21-25.

Sanderson, T., \& Ahmadi-Esfahani, F. Z. (2009). Testing Comparative Advantage in Australian Broadacre Agriculture under Climate Change: Theoretical and Empirical Models. Economic Papers: A Journal of Applied Economics and Policy, 28(4), 346-335.

Santhanam-Martin, M. (2014). Who will be the next round of investors in Australian farming. The Conversation Trust, UK Trust, 4th March, 2014.

Scofield, W. H. (1972). Non-farm equity capital in agriculture. Agricultural Finance Review, 33(July), 36-41.

Shwedel, K. (2007). Value chain financing: A strategy for an orderly, competitive, integrated market. Retrieved from http://www.ruralfi nance.org/id/54079

Spitze, R. G. F. (n.d.). Determinants s of Capital Formation-Conceptual and Factual Consideration, Capital and Credit Needs in Changing Agriculture, Iowa State Press, Ames, 1961.

Spratt, S. (2013). Food price volatility and financial speculation. Future Agricultures Consortium, Working Paper 047.

Stewart, C., Robertson, B., \& Heath, A. (2013). Trends in Funding and Lending Behavior of Australian Banks. 
Research Discussion Paper, Reserve Bank of Australia, 2013-15.

Sun, X. (2002). How to Promote FDI? The Regulatory and Institutional Environment for Attracting FDI. Prepared by Foreign Investment Advisory Service for Capacity Development Workshops and Global Forum on Reinventing Government on Globalization, Role of the State and Enabling Environment, sponsored by United Nations, Marrakech, Morocco, December 10-13. Reardon, Michigan \& B. Barrett. Retrieved from http://www.wtowatch.org/library/admin/uploadedfiles/Agroindustrialization_Globalization_an.d.._I4n/t2e7r $/ \mathrm{n} 0.1 \mathrm{htm}$

Tenebaum, L. (2201). Financial Markets Slam Australian Government over its rejection on Shell Takeover bid. Retrieved from http://www.wsws.org/articles/2001/apr200.shela25.shtml

The Economist. (2009). Green shoots-no matter how bad things get, people still need to eat. The Economist.

Vogel, S. (2006). Farm succession planning in Austria. East European Countryside, 4, 68-78.

Walter, P. (2014). Global Agribusiness Investment: Attractive Long-Term Outlook Generates Interest from Strategic Players and Financial Sponsors.

WB. (2008). World Development Report 2008. Agriculture for Development. The World Bank, Washington D.C.

WB. (2013). Making Sense of Financial Capability Surveys around the World: A Review of Existing Financial Capability and Literacy Measurement Instruments 2013 International Bank for Reconstruction and Development / The World Bank.

WEF. (2011). The Financial Development Report. World Economic Forum Geneva, Switzerland.

WEF. (2014). The Global Competitiveness Report 2013-2014, World Economic Forum Geneva (3rd ed.). Retrieved from http://www.weforum.org/gcr

Wilson, K. (2006). Equity Partnerships Five Years on The National Bank of New Zealand.

Winn, M., Miller, C., \& Gegenbauer, I. (2009). The use of structured finance instruments in agriculture in Eastern Europe and Central Asia. FAO working document, January.

Wonder, B., \& Fisher, B. S. (1990). Agriculture in the economy. In D. B. Williams (Eds.), Agriculture in the Australian Economy (pp. 50-67). Sydney, Sydney University Press.

World Bank. (2008). Agriculture for Development, World Development Report, the World Bank, 1818 H Street, NW Washington DC, 20433.

World Bank. (2014). Global Financial Development Report 2014: Financial Inclusion. Washington, DC: World Bank.

\section{Copyrights}

Copyright for this article is retained by the author(s), with first publication rights granted to the journal.

This is an open-access article distributed under the terms and conditions of the Creative Commons Attribution license (http://creativecommons.org/licenses/by/3.0/). 